\title{
Expression of hormone receptors in oropharyngeal squamous cell carcinoma
}

\section{Mohamed, Hesham}

2018-05

Mohamed, H, Aro , K, Jouhi , L, Makitie , A, Remes , S, Haglund, C , Atula , T \&

Hagstrom , J 2018 , ' Expression of hormone receptors in oropharyngeal squamous cell carcinoma ', European Archives of Oto-Rhino-Laryngology , vol. 275 , no. 5 , pp. 1289-1300

. https://doi.org/10.1007/s00405-018-4949-9

http://hdl.handle.net/10138/301301

https://doi.org/10.1007/s00405-018-4949-9

unspecified

publishedVersion

Downloaded from Helda, University of Helsinki institutional repository.

This is an electronic reprint of the original article.

This reprint may differ from the original in pagination and typographic detail.

Please cite the original version. 


\title{
Expression of hormone receptors in oropharyngeal squamous cell carcinoma
}

\author{
Hesham Mohamed ${ }^{1,2}$ (1) Katri Aro ${ }^{3} \cdot$ Lauri Jouhi $^{3} \cdot$ Antti Mäkitie $^{3,4} \cdot$ Satu Remes ${ }^{1} \cdot$ Caj Haglund $^{5,6} \cdot$ Timo Atula $^{3}$. \\ Jaana Hagström ${ }^{1,6}$
}

Received: 21 December 2017 / Accepted: 21 March 2018 / Published online: 26 March 2018

c) Springer-Verlag GmbH Germany, part of Springer Nature 2018

\begin{abstract}
Objectives Hormone receptors play an important role in many types of cancers. Alongside factors associated with human papillomavirus (HPV) infection, hormonal receptors may impact the tumorigenesis of oropharyngeal cancer.

Materials and methods This study consists of 199 consecutive oropharyngeal squamous cell carcinoma (OPSCC) patients diagnosed and treated with a curative intent. We examined androgen (AR), estrogen (ER; both alpha and beta), and progesterone receptor (PR) expressions using immunohistochemistry comparing tumor and patient characteristics.

Results AR was expressed in 16\%, PR in 27\% and ER-beta in 63\% of the tumors. HPV- and p16-positive tumors expressed more AR and less PR than their negative counterparts. High PR expression was associated with poor disease-specific and locoregional recurrence-free survival.

Conclusion AR, PR, and ER-beta are expressed in OPSCC, and AR and PR expressions are associated with HPV and p16 status. Furthermore, PR appears to have prognostic significance. This may allow us to investigate the role of anti-hormone receptors in the treatment of OPSCC.
\end{abstract}

Keywords Oropharynx $\cdot$ Human papillomavirus $(\mathrm{HPV}) \cdot$ Androgen receptor $\cdot$ Estrogen receptor $\cdot$ Progesterone receptor

\section{Introduction}

Hesham Mohamed, Katri Aro, Timo Atula and Jaana Hagström contributed equally.

Hesham Mohamed

hesham.mohamed@helsinki.fi

1 Department of Pathology, University of Helsinki, HusLab and Helsinki University Hospital, Haartmaninkatu 3, P.O. Box 21, 00014 Helsinki, Finland

2 Department of Histology, Omar Al-Mukhtar University, AlBayda, Libya

3 Department of Otorhinolaryngology, Head and Neck Surgery, University of Helsinki and Helsinki University Hospital, Helsinki, Finland

4 Division of Ear, Nose and Throat Diseases, Department of Clinical Sciences, Intervention and Technology, Karolinska Institutet, Karolinska University Hospital, Stockholm, Sweden

5 Department of Surgery, University of Helsinki and Helsinki University Hospital, Helsinki, Finland

6 Research Programs Unit, Translational Cancer Biology, University of Helsinki, Helsinki, Finland
The landmark study by Ang et al. 2010 firmly established the prognostic implication of human papillomavirus (HPV) in oropharyngeal squamous cell carcinoma (OPSCC) [1]. HPV-related tumors differ from alcohol- and tobaccorelated cancers. Patients with an HPV-related tumor are typically younger, often have a limited history of smoking, and smaller primary tumors, but present with cervical lymphadenopathy, and a generally good prognosis [1-3]. In the latest WHO classification of head and neck tumors from 2017, the HPV-positive and -negative tumors are classified as distinct entities [4]. HPV positivity is detected in over $60 \%$ of OPSCC in USA [5], and in more than $80 \%$ of cases in some European countries [6,7]. Men are more frequently affected $[1,5]$.

While the treatment response of HPV-related OPSCCs is generally good [1], individual variation exists. Identifying factors associated with tumor behavior could enable a more individualized treatment approach. Hormone receptors play a significant role in many types of cancers, and are thus involved in targeted treatments [8]. For example, 
anti-hormone therapies, such as tamoxifen and fulvestrant, are widely used in breast and prostate cancers $[9,10]$. However, in OPSCC, the expression and role of hormone receptors, as well as their association with HPV status remain poorly understood.

Androgen receptors (AR) are primarily male sex-related hormonal receptors. They are expressed by oral mucosal cells [11], and normal prostate and mammary glands [12]. In malignancies, AR expression typically associates with favorable prognoses [13, 14], although not always [15, 16]. Only a few studies have addressed AR expression in head and neck squamous cell carcinoma (HNSCC) [13, 17-20], and very little is known about their expression in OPSCC [13].

Estrogen receptors (ER; types alpha and beta) and progesterone receptors (PR) are nuclear receptors that act as DNAbinding transcription factors. Normal salivary glands and oral mucosal cells in particular express ER-beta [18]. Colella et al. [19] showed an increase of ER-alpha transcription in OSCCs, suggesting the involvement of estrogen hormone in oral cancer. Normal oral mucosa [20], as well as laryngeal and oral SSCs [20-22] express PR, which appears to be a favorable prognostic factor [23].

In this study, we examined the expression of AR, ER, and PR in a series of 201 consecutive OPSCC patients. We compared expression levels with clinical parameters and outcomes. Specially, we explored the relationship between sex hormone receptors and HPV status and the expression of the $\mathrm{p} 16$ protein, which have not been previously studied.

\section{Materials and methods}

\section{Patient selection}

We reviewed data for a total of 331 consecutive patients diagnosed with oropharyngeal cancer at the Department of Otorhinolaryngology-Head and Neck Surgery, Helsinki University Hospital between 1 January 2000 and 31 December 2009. We excluded from the analysis the following patients: patients receiving palliative treatment $(n=44)$, concurrent $(n=5)$ or previously treated HNSCC $(n=11)$, histology other than SCC or subtype of SCC $(n=18)$, tumor tissue unavailability $(n=52)$, or patients without pretreatment samples $(n=2)$. In total, our final study cohort consisted of 199 patients treated with a curative intent and for whom tumor tissue was available for HPV, p16, and hormone receptor analysis.

\section{Data source from hospital records}

We collected clinicopathological data on patient's age, sex, tumor histology, grade, TNM classification [24], stage, primary treatment, tumor recurrence and status at last follow-up. The median follow-up time for patients was 5.0 years, and all patients had a minimum follow-up of 3 years or until death. The dates and causes of death were obtained from Statistics Finland. The Research Ethics Board of the Hospital District of Helsinki and Uusimaa approved the study design and granted permission to conduct this study. Patient data are described in further detail in our previous study [25].

From our 199 patients, 130 (65\%) underwent primary surgery and $116(89 \%)$ received postoperative radiotherapy (RT) or chemoradiotherapy (CRT). In total, 14 (11\%) patients remained who did not receive postoperative RT or CRT: five due to stage I or II disease and nine due to patient-related factors. A total of 69 (35\%) patients received definitive oncological treatment (RT or CRT), 9 of whom underwent complementary surgery during the primary treatment phase.

\section{Immunohistochemical staining}

Preparation of tissue microarray (TMA) blocks and immunohistochemical staining was completed as described previously [26]. TMA blocks were cut into $4 \mu \mathrm{m}$ thick sections, deparaffinized in xylene, and rehydrated through a graded alcohol series. Antigen retrieval was achieved by heating the samples in a $98{ }^{\circ} \mathrm{C}$ Tris- $\mathrm{HCl}$ buffer (pH8.5) for 20 min in a pretreatment PT module (Lab Vision Corp., Fremont, CA, USA). Samples were cooled to room temperature and incubated in methanol containing $1.6 \%$ hydrogen peroxidase for $30 \mathrm{~min}$ and then treated with horse serum to block the non-specific binding sites. The immunostaining was performed in Autostainer 480 (LabVision) with the following antibodies: monoclonal antibody (mAb) ERalpha diluted to 1:100 (Leica Biosystem Newcastle Ltd), mAb ER-beta diluted to 1:100 (Leica Biosystem Newcastle Ltd), and mAb PR diluted to 1:100 (Leica Biosystem Newcastle Ltd). Stainings were visualized using the Dako Real Detection System. MAb PR reacts with both progesterone receptors A and B (PR-A and PR-B). We used Discovery Automated IHC stainer with the ultraView Universal Alkaline Phosphatase Red Detection Kit (catalog no. 760-501, Ventana Medical Systems, Tuscon, Arizona, USA) in the staining of mAb AR diluted to 1:50 (Dako, Agilent Technologies, Santa Clara, California, US). Breast cancer tissue served as the positive control for each antibody. In each staining, a slide without a primary antibody served as the negative control.

p16 immunohistochemical staining for this series was performed in our previous study [25], in which we used monoclonal mouse anti-human p16INK4a (9517 CINtec Histology Kit, MTM laboratories). 


\section{HPV in situ hybridization}

HPV in situ hybridization was performed in our previous study [25]. We performed the Ventana Inform HPV in situ hybridization (ISH) assay using a high-risk HPV probe $(16,18,31,33,35,39,45,51,52,56,58$, and 66) and iVIEW Blue detection kit in Benchmark XT series stainer (Tuscon, Arizona, USA). To perform the assay, we used 5 - $\mu \mathrm{m}$ thick sections and extended Ventana cell-conditioning solution (CC2) pretreatment with an incubation time of 32 min with ISH protease 3 . We considered HPV status as positive if any spot was positive using ISH.

\section{Immunoscoring}

Two researchers (JH and HM) individually evaluated the TMA slides in a blinded manner without knowledge of the clinicopathological data. In the case of a discrepancy, a consensus score was used for further analysis. AR and ER-beta expressions were nuclear and scored according to the percentage as negative $=(0),<10 \%=$ mild (1), $10-50 \%=$ moderate $(2)$, and $>50 \%=$ strong (3). PR expression was cytoplasmic and scored according to the intensity as negative (0), mild (1), moderate (2), and strong (3). From tumor spots, we assigned the highest immunoscore for further analysis. Since all tumor samples remained negative for ER-alpha, no scoring was performed.

We used whole tissue slides to examine the staining patterns across the entire tumor sample. In total, ten whole tumor slides were stained for AR and PR and eight for ERbeta. The staining of whole slides for AR, PR and ER-beta showed similarity to the staining seen in TMA slides.

\section{Statistical analysis}

We used SPSS version 20 (SPSS, Inc. Chicago, IL, USA) for all statistical analyses. We calculated the statistical significance of differences between categorical variables using the Pearson's Chi square test, selecting asymptomatic or exact $p$ values when suitable. Our prognostic model was the Kaplan-Meier (KM) estimate with the logrank test, wherein we used death from disease (diseasespecific survival, DSS) or locoregional or distant recurrence (recurrence-free survival, RFS) as the endpoint. The Cox proportional hazards model served in the multivariate analysis of prognostic factors. The proportional hazards assumption was tested using KM curves. Factors with a univariate $p$ value of $<0.1$ were selected for multivariate analysis. A two-sided $p$ value of $<0.05$ was considered statistically significant.

\section{Results}

\section{Expression of AR}

AR expression was detected in 16\% (31/199) of the tumors, of which 39\% (12/31) showed mild, and 61\% (19/31) strong expression (Table 1). None of the samples showed moderate staining. In the whole tissue samples, AR expression appeared predominantly along the invasive front (Fig. 1).

AR expression appeared more often in HPV- and p16-positive tumors than in HPV- and p16-negative tumors. Among men, 17\% (25/147) of samples were AR positive, which fell to $12 \%$ (6/52) in women. In addition, AR expression was stronger among non-smokers or ex-smokers. We found no association between AR expression and the use of alcohol, tumor site, grade, TNM class, stage, DSS, or RFS (Table 1; Fig. 2).

\section{Expression of ER}

ER-beta expression was present in 63\% (126/199) of samples, which was mild in $36 \%$ (45/126), moderate in $29 \%$ (36/126) and strong in 36\% (45/126) of immunopositive tumors (Table 2). In whole tissue samples, ER-beta expression appeared both along the central and invasive regions, in addition to the basal layer of normal epithelium (Fig. 1).

We found no statistical association between ER-beta and p16 or HPV status, nor with any of the patient or tumor characteristics, DSS, or RFS. All tumors remained negative for ER-alpha (Table 2; Fig. 2).

\section{Expression of PR}

PR was expressed in 27\% (54/199) of tumors, with mild in $35 \%(19 / 54)$, moderate in $46 \%(25 / 54)$, and strong in $19 \%$ (10/54) of the immunopositive tumors (Table 3). In whole tissue samples, PR expression was predominantly seen along the central part of the tumor, but not along the invasive front or invasive islands (Fig. 1).

PR expression appeared more commonly in HPV- and p16-negative tumors than in HPV- and p16-positive tumors (Table 3; Fig. 3). Smokers or ex-smokers exhibited a stronger PR tumor expression than non-smokers, often with a history of heavy alcohol use (Table 3). In addition, PR expression associated with the tumor grade. High-grade tumors (often linked to HPV) showed significantly lower PR expression than tumors of lower grades $(p<0.001)$. We found no association between PR expression and sex, TNM class, or stage. In addition, patients with a strong PR tumor expression had worse 5-year DSS than those with negative staining ( $p=0.001)$ (Fig. 2). Similarly, patients exhibiting 
Table 1 Expression of androgen receptors and its association with clinicopathological factors in OPSCC

\begin{tabular}{|c|c|c|c|c|c|}
\hline \multirow[t]{2}{*}{ Variables } & \multicolumn{4}{|c|}{ Androgen receptor scoring } & \multirow[t]{2}{*}{$p$ value } \\
\hline & Negative & Weak & Strong & Total number & \\
\hline \multicolumn{6}{|l|}{ Sex } \\
\hline Men & 122 & 8 & 17 & 147 & \\
\hline Women & 46 & 4 & 2 & 52 & \\
\hline Total & 168 & 12 & 19 & 199 & $0.196 * *$ \\
\hline \multicolumn{6}{|l|}{ Smoking } \\
\hline Never & 19 & 2 & 5 & 26 & \\
\hline Ex-smoker & 39 & 2 & 6 & 47 & \\
\hline Regularly & 88 & 5 & 2 & 95 & \\
\hline Total & 146 & 9 & 13 & 168 & $0.002 * *$ \\
\hline \multicolumn{6}{|l|}{ Alcohol abuse } \\
\hline No & 51 & 2 & 8 & 61 & \\
\hline Previously & 22 & 1 & 0 & 23 & \\
\hline Yes & 32 & 3 & 2 & 37 & \\
\hline Total & 105 & 6 & 10 & 121 & $0.329 * *$ \\
\hline \multicolumn{6}{|l|}{ HPV } \\
\hline Positive & 74 & 11 & 18 & 103 & \\
\hline Negative & 94 & 1 & 1 & 96 & \\
\hline Total & 168 & 12 & 19 & 199 & $<0.001 *$ \\
\hline \multicolumn{6}{|l|}{ p16 } \\
\hline Positive & 86 & 10 & 19 & 115 & \\
\hline Negative & 82 & 2 & 0 & 84 & \\
\hline Total & 168 & 12 & 19 & 199 & $<\mathbf{0 . 0 0 1} * *$ \\
\hline \multicolumn{6}{|l|}{ Grade } \\
\hline Gr1 & 16 & 2 & 0 & 18 & \\
\hline Gr2 & 66 & 3 & 6 & 75 & \\
\hline Gr3 & 86 & 7 & 13 & 106 & \\
\hline Total & 168 & 12 & 19 & 199 & $0.135^{* *}$ \\
\hline \multicolumn{6}{|l|}{ Tumor site } \\
\hline Anterior wall & 53 & 2 & 4 & 59 & \\
\hline Lateral wall & 91 & 10 & 15 & 116 & \\
\hline Posterior wall & 3 & 0 & 0 & 3 & \\
\hline Superior wall & 21 & 0 & 0 & 21 & \\
\hline Total & 168 & 12 & 19 & 199 & $0.426 * *$ \\
\hline \multicolumn{6}{|l|}{$\mathrm{T}$ class } \\
\hline $\mathrm{T} 1$ & 33 & 1 & 4 & 38 & \\
\hline $\mathrm{T} 2$ & 60 & 7 & 7 & 74 & \\
\hline $\mathrm{T} 3$ & 38 & 1 & 6 & 45 & \\
\hline $\mathrm{T} 4$ & 37 & 3 & 2 & 42 & \\
\hline Total & 168 & 12 & 19 & 199 & $0.616^{* *}$ \\
\hline \multicolumn{6}{|l|}{$\mathrm{N}$ class } \\
\hline No & 37 & 1 & 1 & 39 & \\
\hline $\mathrm{N}+$ & 131 & 11 & 18 & 160 & \\
\hline Total & 168 & 12 & 19 & 199 & $0.057 * *$ \\
\hline \multicolumn{6}{|l|}{ Stage } \\
\hline I-II & 29 & 0 & 1 & 30 & \\
\hline III-IV & 139 & 12 & 18 & 169 & \\
\hline Total & 168 & 12 & 19 & 199 & $0.077 * *$ \\
\hline
\end{tabular}

$p$ values indicated in bold are significant

*Chi square test with asymptotic $p$ value

**Chi square test with exact $p$ value a strong PR expression had lower 5-year locoregional RFS rate than those with negative staining $(p=0.041)$ (Fig. 2), although PR expression did not associate with distant RFS.

In the multivariate analysis, high PR expression conferred a 3.8-fold risk of death of disease (Table 4). Other independent factors for poor prognosis included HPV negativity, $\mathrm{T} 4$ class, $\mathrm{N} 2-3$ classes, and male gender.

\section{Discussion}

In this study, we demonstrate the expression of AR, ER, and PR in tumor samples in a series of 199 OPSCC patients. We found that a strong PR expression was associated with shorter DSS and RFS. In addition, we found that both HPV and $\mathrm{p} 16$ positivity associated with the upregulation of AR and the downregulation of PR expression, although they did not associate with ER expression. In cervical cancer, Bekkers et al. [27] have suggested that ER downregulation may represent the first alteration occurring in normal epithelium during carcinogenesis. To date, we have found no previous studies connecting AR and HPV, a relationship requiring further investigations.

Both OPSCC and laryngeal carcinoma occur more frequently in men $[5,28]$. This could be partly explained by men being more often exposed to high-risk behaviors such as tobacco, alcohol use, and oral sex [29]. In accordance with this, $74 \%$ of our samples were from male patients. Our study revealed no statistical association between hormone receptor expressions and sex, although the AR high immunoexpression occurred primarily among men. In tongue SCC, Marocchio et al. [30] found that men presented with AR positivity more often, whereas ER expression did not differ between men and women. A study by Goulioumis et al. [31] showed that more than $50 \%$ of laryngeal carcinomas are AR immunopositive. By contrast, Bianchini et al. [21] found no AR positivity in laryngeal carcinoma, although ER expression appeared in 53\% and PR expression in 73\% of the tumors, and these expressions were associated with an absence of lymph node metastasis. In the present study, we were not able to show any relation between PR expression and occurrence of lymph node metastasis. However, our results revealed an association between PR positivity and HPV negativity in the samples and it is known that the pattern of metastatic disease is different between HPV-negative and -positive OPSCC. This phenomenon remains to be further investigated.

In our series, $16 \%$ of the tumors were AR positive, with the strongest expression occurring along the invasive front. AR appears to be related to the development of cancers by increasing cell migration and invasion [32]. In oral cavity SCC, findings appear contradictory: for instance, Nehse and Tunn [20] revealed that the expression of AR was lower in 

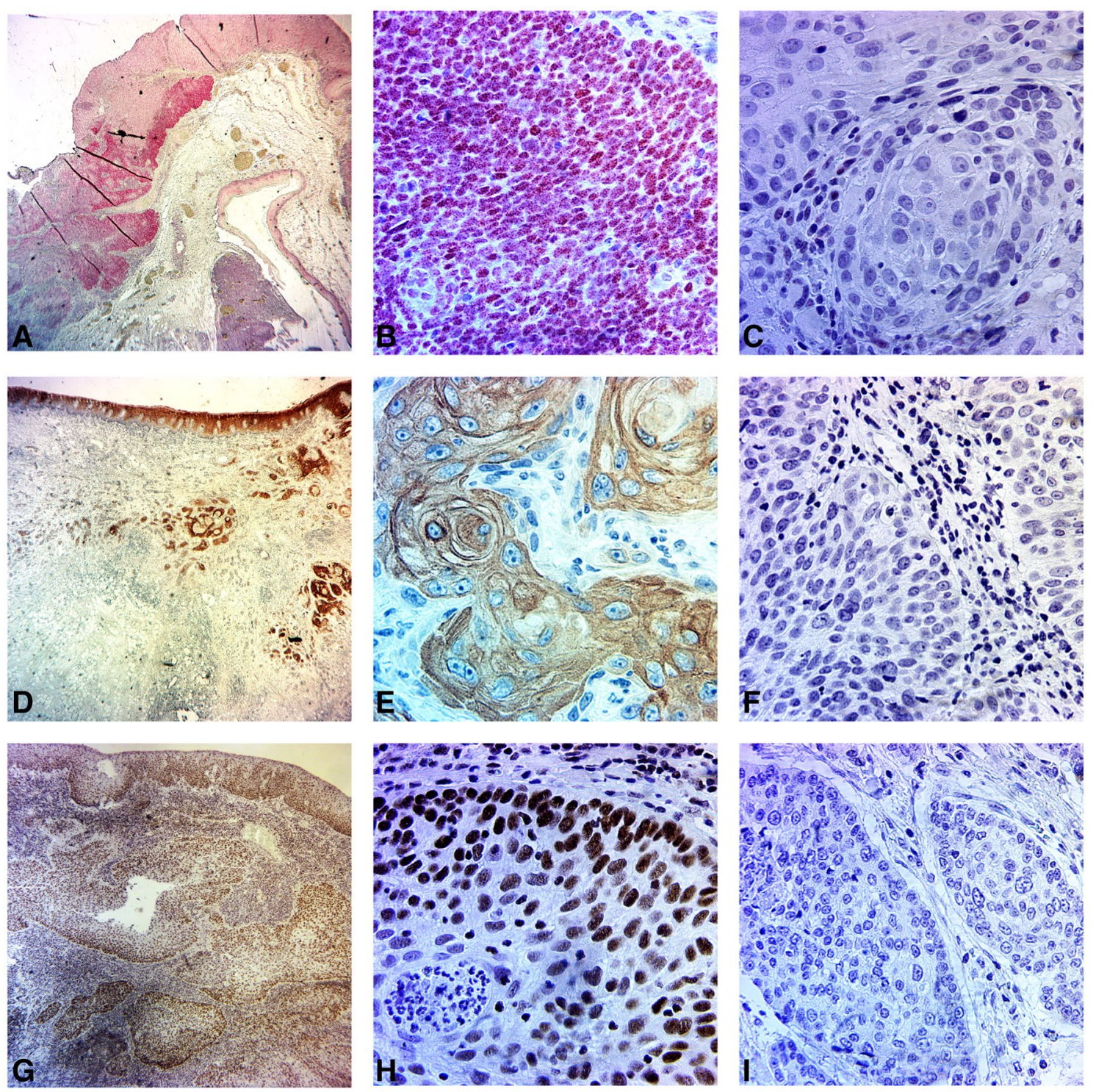

Fig. 1 Immunohistochemical staining pattern of AR, PR, and ERbeta receptors in oropharyngeal carcinoma. a OPSCC with positive nuclear AR expression (magnification $\times 40$ ), in which the expression appears along the invasive front. b OPSCC with positive nuclear AR expression (magnification $\times 400$ ). $\mathbf{c}$ OPSCC with negative AR expression (magnification $\times 400$ ). d OPSCC with positive cytoplasmic PR expression (magnification $\times 40$ ), in which the expression appears along the central part of the tumor rather than the invasive front. e
OPSCC with positive cytoplasmic PR expression (magnification $\times 400$ ). f OPSCC with negative PR expression (magnification $\times 400$ ). g OPSCC with positive nuclear ER-beta expression (magnification $\times 40$ ), in which the expression appears both along the central and invasive parts, and in addition along the basal layer of normal epithelium. h OPSCC with positive nuclear ER expression (magnification $\times 400)$. i OPSCC with negative ER expression (magnification $\times 400$ )
SCC than in the normal oral mucosa. Yet, Wu et al. [17] reported opposing results, finding that $67 \%$ of OSCC specimens were AR positive. These contradictory reports may result from the different methods used in these two studies.

ER carries several physiological functions, having a role in the growth and behavior of cancers, particularly in breast cancer [33]. Lopez-Romero et al. [34] showed that cervical malignant cells lose their ER-alpha expression, but maintain the ER-beta expression. In addition, it has been shown that
HPV-infected cervical dysplasia exhibits ER downregulation [27]. Furthermore, a study on lingual SCC revealed that tumors only expressed ER-beta [35]. These studies are consistent with our findings showing that OPSCC expresses ER-beta but not ER-alpha. However, Gingelmaier et al. [36] reported that neither ER-alpha nor ER-beta were expressed in HPV-positive adenosquamous endometrial carcinoma.

In our cohort, $27 \%$ of the tumors expressed PR. A study by Grimm et al. [37] found no expression of PR 

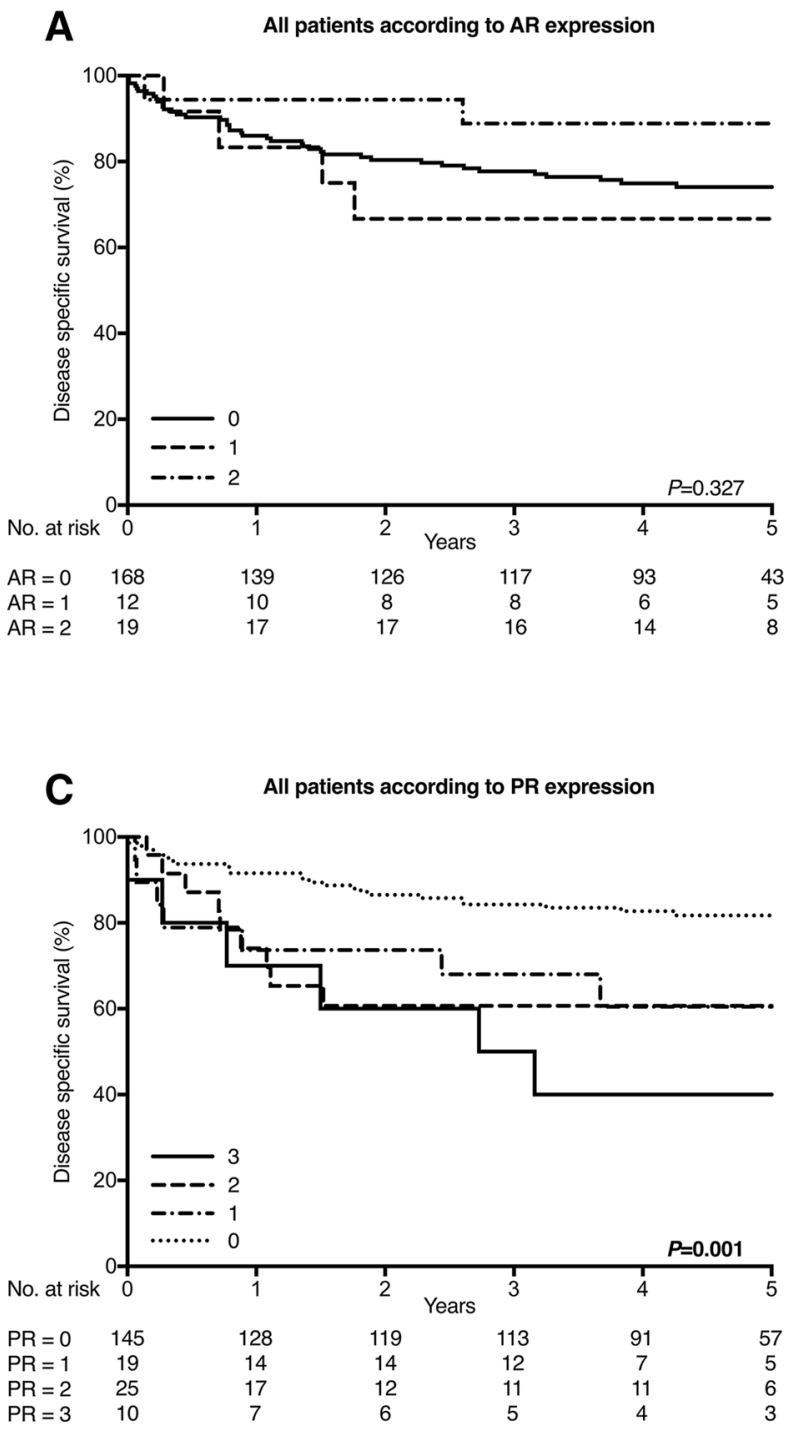

Fig. 2 Using the Kaplan-Meier, a disease-specific survival (DSS) curve for 199 patients in relation to AR expression, b disease-specific survival (DSS) curve for 199 patients in relation to ER-beta expres-

in OSCC. Another study by Nehse and Tunn [20] found PR present in only $40 \%$ of OSCC, and in all normal oral mucosa samples. In our series, PR expression was cytoplasmic, although staining for PR is typically nuclear, such as in our control slides. This cytoplasmic positivity may result from the different isoforms of PR. Some of these isoforms carry a defective DNA-binding domain lacking the nuclear localization signal [38]. A similar unusual cytoplasmic expression pattern was detected with an ERbeta isomer in ovarian cancer [39]. This suggests that the pathogenesis of some types of cancer may cause a defect in DNA-binding site for hormone receptors. In our study, PR expression appeared in HPV- and p16-negative tumors, behaving more aggressively, and significantly correlating with worse outcomes.
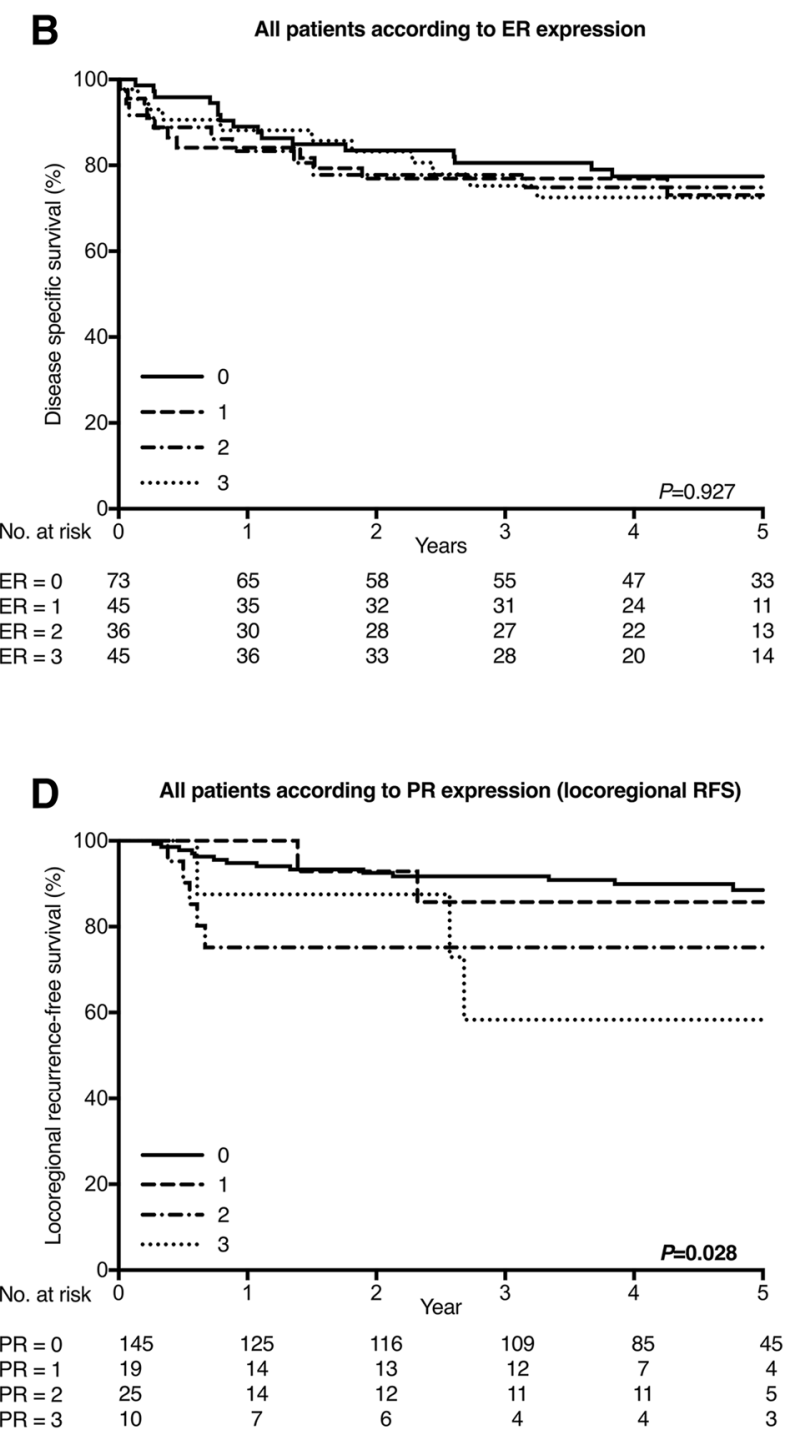

sion, c disease-specific survival (DSS) curve for 199 patients in relation to PR expression, $\mathbf{d}$ locoregional recurrence-free survival curve for 199 patients in relation to $\mathrm{PR}$ expression

In many malignancies, hormone receptors correlate with aggressiveness and the metastatic potential of the tumors [35, 40, 41]. In terms of survival, findings remain inconsistent. In our cohort, only PR expression is associated with survival. A positive prognostic role for high AR expression has been shown for various malignant tumors, i.e., bladder [42], breast [14], and prostate cancer [43]. A study on HNSCC by Rades et al. [13] showed that the expression of $\mathrm{AR}$ is an independent prognostic factor for better survival in advanced stage diseases. Conversely, in some other cancers, such as prostate [41], esophageal [32], and thyroid cancer [44], AR expression correlates with more aggressive tumors. In addition, a poor prognosis accompanies salivary duct carcinoma with 70 to $98 \%$ of tumors showing AR immunopositivity $[15,16]$. We found no correlation between AR or ER 
Table 2 Expression of estrogen-beta receptors and its association with clinicopathological factors in OPSCC

\begin{tabular}{|c|c|c|c|c|c|c|}
\hline \multirow[t]{2}{*}{ Variables } & \multicolumn{5}{|c|}{ Estrogen-beta receptor scoring } & \multirow[t]{2}{*}{$p$ value } \\
\hline & Negative & Weak & Moderate & Strong & Total number & \\
\hline \multicolumn{7}{|l|}{ Sex } \\
\hline Men & 55 & 31 & 27 & 34 & 147 & \\
\hline Women & 18 & 14 & 9 & 11 & 52 & \\
\hline Total & 73 & 45 & 36 & 45 & 199 & $0.907 *$ \\
\hline \multicolumn{7}{|l|}{ Smoking } \\
\hline Never & 5 & 10 & 5 & 6 & 26 & \\
\hline Ex-smoker & 20 & 9 & 6 & 12 & 47 & \\
\hline Regularly & 30 & 19 & 22 & 24 & 95 & \\
\hline Total & 55 & 38 & 33 & 42 & 168 & $0.824^{*}$ \\
\hline \multicolumn{7}{|l|}{ Alcohol abuse } \\
\hline No & 20 & 16 & 13 & 12 & 61 & \\
\hline Previously & 8 & 4 & 2 & 9 & 23 & \\
\hline Yes & 10 & 9 & 10 & 8 & 37 & \\
\hline Total & 38 & 29 & 25 & 29 & 121 & $0.480^{*}$ \\
\hline \multicolumn{7}{|l|}{ HPV } \\
\hline Positive & 38 & 30 & 17 & 18 & 103 & \\
\hline Negative & 35 & 15 & 19 & 27 & 96 & \\
\hline Total & 73 & 45 & 36 & 45 & 199 & $0.134^{*}$ \\
\hline \multicolumn{7}{|l|}{ p16 } \\
\hline Positive & 41 & 32 & 20 & 22 & 115 & \\
\hline Negative & 32 & 13 & 16 & 23 & 84 & \\
\hline Total & 73 & 45 & 36 & 45 & 199 & $0.353^{*}$ \\
\hline \multicolumn{7}{|l|}{ Grade } \\
\hline Gr1 & 8 & 2 & 3 & 5 & 18 & \\
\hline Gr2 & 25 & 21 & 12 & 17 & 75 & \\
\hline Gr3 & 40 & 22 & 21 & 23 & 106 & \\
\hline Total & 73 & 45 & 36 & 45 & 199 & $0.927 * *$ \\
\hline \multicolumn{7}{|l|}{ Tumor site } \\
\hline Anterior wall & 19 & 13 & 12 & 15 & 59 & \\
\hline Lateral wall & 47 & 27 & 18 & 24 & 116 & \\
\hline Posterior wall & 1 & 0 & 1 & 1 & 3 & \\
\hline Superior wall & 6 & 5 & 5 & 5 & 21 & \\
\hline Total & 73 & 45 & 36 & 45 & 199 & $0.972 * *$ \\
\hline \multicolumn{7}{|l|}{$\mathrm{T}$ class } \\
\hline $\mathrm{T} 1$ & 15 & 8 & 8 & 7 & 38 & \\
\hline $\mathrm{T} 2$ & 27 & 19 & 12 & 16 & 74 & \\
\hline T3 & 13 & 13 & 9 & 10 & 45 & \\
\hline $\mathrm{T} 4$ & 18 & 5 & 7 & 12 & 42 & \\
\hline Total & 73 & 45 & 36 & 45 & 199 & $0.528^{*}$ \\
\hline \multicolumn{7}{|l|}{$\mathrm{N}$ class } \\
\hline N0 & 16 & 6 & 4 & 13 & 39 & \\
\hline $\mathrm{N}+$ & 57 & 39 & 32 & 32 & 160 & \\
\hline Total & 73 & 45 & 36 & 45 & 199 & $0.584^{*}$ \\
\hline \multicolumn{7}{|l|}{ Stage } \\
\hline I-II & 10 & 5 & 3 & 12 & 30 & \\
\hline III-IV & 63 & 40 & 33 & 33 & 169 & \\
\hline Total & 73 & 45 & 36 & 45 & 199 & $0.130 *$ \\
\hline
\end{tabular}

*Chi square test with asymptotic $p$ value

**Chi square test with exact $p$ value 
Table 3 Expression of progesterone receptors and its association with clinicopathological factors in OPSCC

\begin{tabular}{|c|c|c|c|c|c|c|}
\hline \multirow[t]{2}{*}{ Variables } & \multicolumn{5}{|c|}{ Progesterone receptor scoring } & \multirow[t]{2}{*}{$p$ value } \\
\hline & Negative & Weak & Moderate & Strong & Total number & \\
\hline \multicolumn{7}{|l|}{ Sex } \\
\hline Men & 113 & 12 & 14 & 8 & 147 & \\
\hline Women & 32 & 7 & 11 & 2 & 52 & \\
\hline Total & 145 & 19 & 25 & 10 & 199 & $0.106 * *$ \\
\hline \multicolumn{7}{|l|}{ Smoking } \\
\hline Never & 24 & 2 & 0 & 0 & 26 & \\
\hline Ex-smoker & 42 & 1 & 3 & 1 & 47 & \\
\hline Regularly & 55 & 16 & 16 & 8 & 95 & \\
\hline Total & 121 & 19 & 19 & 9 & 168 & $<0.001 * *$ \\
\hline \multicolumn{7}{|l|}{ Alcohol abuse } \\
\hline No & 51 & 4 & 5 & 1 & 61 & \\
\hline Previously & 15 & 3 & 2 & 3 & 23 & \\
\hline Yes & 21 & 5 & 6 & 5 & 37 & \\
\hline Total & 87 & 12 & 13 & 9 & 121 & $\mathbf{0 . 0 0 3}^{* *}$ \\
\hline \multicolumn{7}{|l|}{ HPV } \\
\hline Positive & 91 & 5 & 7 & 0 & 103 & \\
\hline Negative & 54 & 14 & 18 & 10 & 96 & \\
\hline Total & 145 & 19 & 25 & 10 & 199 & $<0.001 * *$ \\
\hline \multicolumn{7}{|l|}{ p16 } \\
\hline Positive & 102 & 5 & 7 & 1 & 115 & \\
\hline Negative & 43 & 14 & 18 & 9 & 84 & \\
\hline Total & 145 & 19 & 25 & 10 & 199 & $<0.001 *$ \\
\hline \multicolumn{7}{|l|}{ Grade } \\
\hline Gr1 & 6 & 5 & 4 & 3 & 18 & \\
\hline Gr2 & 45 & 9 & 14 & 7 & 75 & \\
\hline Gr3 & 94 & 5 & 7 & 0 & 106 & \\
\hline Total & 145 & 19 & 25 & 10 & 199 & $<\mathbf{0 . 0 0 1} * *$ \\
\hline \multicolumn{7}{|l|}{ Tumor site } \\
\hline Anterior wall & 43 & 6 & 9 & 1 & 59 & \\
\hline Lateral wall & 92 & 7 & 12 & 5 & 116 & \\
\hline Posterior wall & 1 & 0 & 1 & 1 & 3 & \\
\hline Superior wall & 9 & 6 & 3 & 3 & 21 & \\
\hline Total & 145 & 19 & 25 & 10 & 199 & $0.014 * *$ \\
\hline \multicolumn{7}{|l|}{$\mathrm{T}$ class } \\
\hline $\mathrm{T} 1$ & 33 & 3 & 1 & 1 & 38 & \\
\hline $\mathrm{T} 2$ & 51 & 8 & 10 & 5 & 76 & \\
\hline T3 & 33 & 3 & 6 & 3 & 45 & \\
\hline $\mathrm{T} 4$ & 28 & 5 & 8 & 1 & 42 & \\
\hline Total & 145 & 19 & 25 & 10 & 199 & $0.155^{* *}$ \\
\hline \multicolumn{7}{|l|}{$\mathrm{N}$ class } \\
\hline No & 24 & 6 & 6 & 3 & 39 & \\
\hline $\mathrm{N}+$ & 121 & 13 & 19 & 7 & 160 & \\
\hline Total & 145 & 19 & 25 & 10 & 199 & $0.136^{* *}$ \\
\hline \multicolumn{7}{|l|}{ Stage } \\
\hline I-II & 18 & 5 & 4 & 3 & 30 & \\
\hline III-IV & 127 & 14 & 21 & 7 & 169 & \\
\hline Total & 145 & 19 & 25 & 10 & 199 & $0.122 * *$ \\
\hline
\end{tabular}



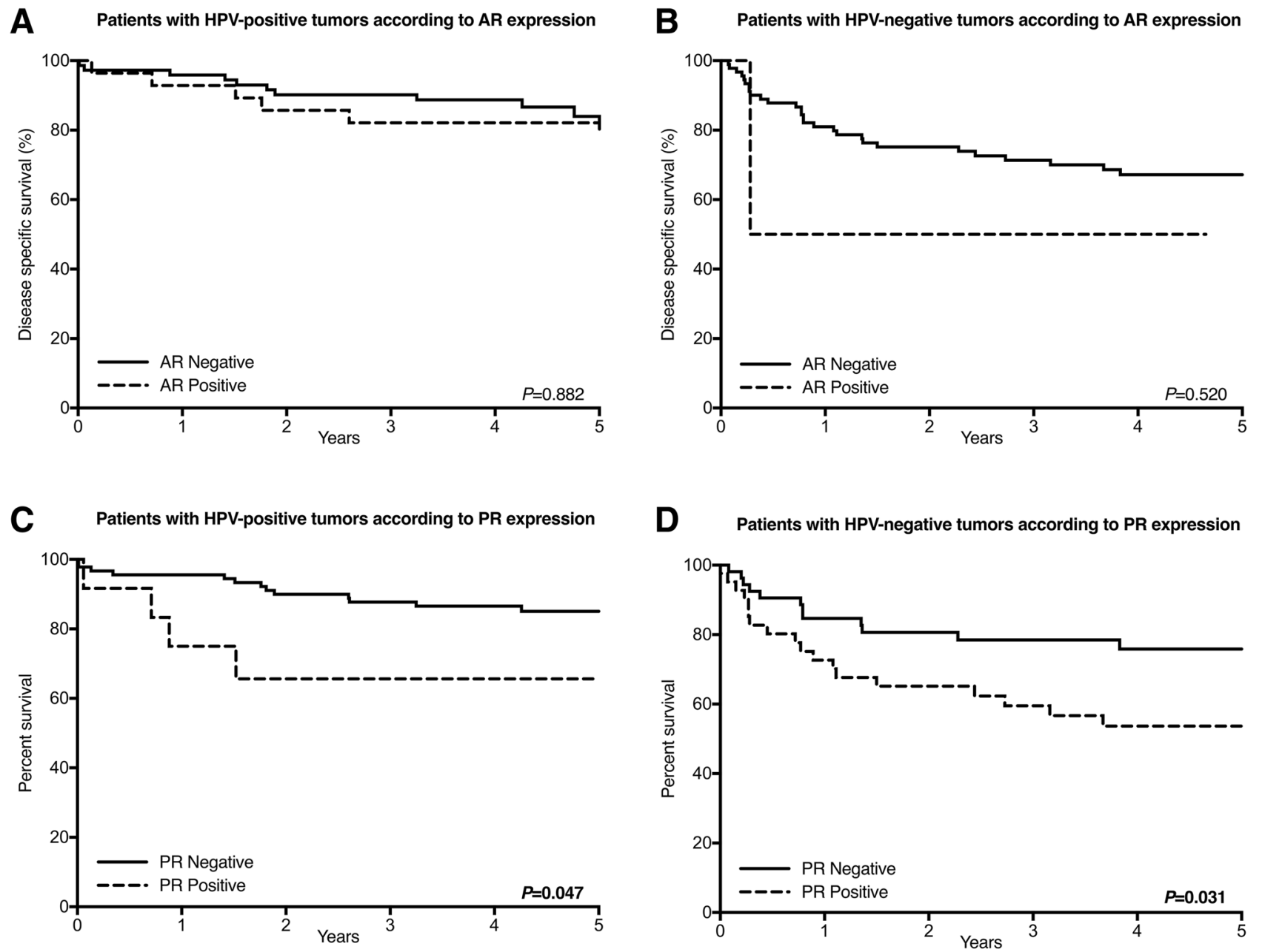

Fig. 3 Using the Kaplan-Meier, $\mathbf{a}$ and $\mathbf{b}$ disease specific survival (DSS) curves for 199 patients in relation to AR in HPV subgroups, $\mathbf{c}$ and $\mathbf{d}$ disease specific survival (DSS) curves for 199 patients in relation to PR in HPV subgroups

expression and survival. Yet, a study by Lukits et al. [45] combining laryngeal and hypopharyngeal SCCs showed that ER positivity associates with poor survival.

Currently, anti-hormone therapy stands as one of the primary treatment options for various types of cancers. Stromal PR may play a suppressive role in prostate cancer enabling its use as a therapeutic target [46]. In vitro studies suggest that anti-hormone agents, such as tamoxifen, could have a therapeutic role in OSCC [35] and HNSCC in general [47]. However, this hypothesis thus so far has not been supported by in vivo studies, showing either a complete lack [48], or low expression [49] of hormone receptors in laryngeal cancer.

In the present study, AR positivity was found more often among non-smokers, while PR positivity was more frequent among smokers and ex-smokers. Strikingly, a high proportion of our patients were current or former smokers: $98 \%$ of patients with a non-HPV-related tumor and $72 \%$ of patients with an HPV-related tumor (data not shown). The impact of smoking history on the etiology and treatment response of HPV-positive OPSCC remains unclear, although smoking significantly increases the likelihood of death [1].

The retrospective nature of our study results in certain limitations. Our data were limited particularly in relation to smoking and alcohol misuse. Furthermore, the number of patients from certain subgroups, such as that with a strong AR positivity remained limited and potentially impacting our findings on tumor pathogenesis, which was not revealed in our study. However, our material was homogeneous consisting of OPSCCs with solid follow-up data. Furthermore, we could include information on both HPV and p16 status. Yet, pretreatment samples remained unavailable for two patients, and the treatment effect on hormone receptor expression in these two patients could not be eliminated. However, excluding these patients did not affect our results. 
Table 4 Univariate and multivariate Cox regression analysis for disease-specific survival

\begin{tabular}{|c|c|c|c|c|c|c|}
\hline \multirow[t]{2}{*}{ Variables } & \multicolumn{3}{|c|}{ Univariate analysis } & \multicolumn{3}{|c|}{ Multivariate analysis } \\
\hline & HR & CI $95 \%$ & $p$ value & HR & CI 95\% & $p$ value \\
\hline \multicolumn{7}{|l|}{ Sex } \\
\hline Male vs. female & 2.2 & $1.0-4.9$ & 0.054 & 2.4 & $1.1-5.7$ & 0.035 \\
\hline Smoking & & & 0.038 & & & \\
\hline Earlier vs. never & 1.7 & $0.5-6.0$ & 0.439 & & & \\
\hline Currently vs. never & 3.3 & 1.0-10.7 & 0.048 & & & \\
\hline $\mathrm{T}$ class & & & 0.060 & & & 0.056 \\
\hline $\mathrm{T} 2$ vs. T1 & 3.0 & $0.7-5.3$ & 0.178 & 2.2 & $0.8-6.3$ & 0.123 \\
\hline T3 vs. T1 & 1.8 & $0.6-5.3$ & 0.284 & 1.6 & $0.6-4.9$ & 0.374 \\
\hline T4 vs. T1 & 3.6 & $1.3-10.0$ & 0.013 & 3.7 & $1.3-10.2$ & 0.013 \\
\hline \multicolumn{7}{|l|}{$\mathrm{N}$ class } \\
\hline N2-3 vs. N0-1 & 2.1 & $1.0-4.2$ & $\mathbf{0 . 0 3 7}$ & 2.7 & $1.3-5.7$ & 0.009 \\
\hline AR & & & 0.352 & & & \\
\hline 1 vs. 0 & 1.4 & $0.5-3.6$ & 0.557 & & & \\
\hline 2 vs. 0 & 0.4 & $0.1-1.6$ & 0.201 & & & \\
\hline PR & & & 0.002 & & & $\mathbf{0 . 0 2 6}$ \\
\hline 1 vs. 0 & 2.5 & $1.1-5.7$ & 0.034 & 2.3 & $1.0-5.5$ & 0.064 \\
\hline 2 vs. 0 & 2.7 & $1.3-5.8$ & 0.011 & 2.2 & $1.0-5.1$ & 0.054 \\
\hline 3 vs. 0 & 4.3 & 1.8-10.5 & 0.001 & 3.8 & $1.4-10.2$ & 0.008 \\
\hline ER & & & 0.927 & & & \\
\hline 1 vs. 0 & 1.2 & $0.6-2.7$ & 0.595 & & & \\
\hline 2 vs. 0 & 1.2 & $0.5-2.7$ & 0.653 & & & \\
\hline 3 vs. 0 & 1.3 & $0.6-2.7$ & 0.569 & & & \\
\hline \multicolumn{7}{|l|}{ HPV } \\
\hline HPV- vs. HPV+ & 2.2 & $1.2-4.0$ & 0.007 & 2.0 & $1.0-4.0$ & 0.040 \\
\hline \multicolumn{7}{|l|}{ Treatment } \\
\hline (C)RT $\pm \mathrm{Sx}$ vs. $\mathrm{Sx} \pm(\mathrm{C}) \mathrm{RT}$ & 1.0 & $0.6-1.8$ & 0.975 & & & \\
\hline
\end{tabular}

$H R$ hazard ratio, $C I$ confidence interval

$p$ values indicated in bold are significant

\section{Conclusion}

To our knowledge, this is the first study to assess hormone receptors specifically in HPV-related and non-HPVrelated OPSCC. We found that AR expression appeared along the invasive front of the tumor more commonly in HPV-related tumors. In contrast, PR expression more often accompanied HPV-negative tumors, being cytoplasmic along the central part of the tumor. In addition, PR expression is associated with poor DSS. This indicates that further studies in future are necessary to explore their role in OPSCC, as well as the possible benefit of targeted therapies for such patients.

Funding This work was supported by the Helsinki University Hospital Research Funds, the Sigrid Jusélius Foundation, the Otorhinolaryngology Research Foundation, Finnish Dental Association, Apollonia, and Libyan Ministry of Higher Education and Scientific Research.

\section{Compliance with ethical standards}

Conflict of interest The authors declare that they have no conflict of interest.

Ethical approval The project is part of a larger research project regarding oropharyngeal cancer at the Dept. of Otorhinolaryngology Head and Neck Surgery $(\mathrm{HUCH})$, and an institutional review board approval was obtained from the Research Ethics Committee of the Helsinki University Hospital (HUS). In addition, a hospital study permission was granted (Dnro179/13/03/02/2013). All procedures performed in studies involving human participants were in accordance with the ethical standards of the institutional and/or national research committee and with the 1964 Helsinki declaration and its later amendments or comparable ethical standards. 


\section{References}

1. Ang KK, Harris J, Wheeler R, Weber R, Rosenthal DI, NguyenTan PF, Westra WH, Chung CH, Jordan RC, Lu C, Kim H, Axelrod R, Silverman CC, Redmond KP, Gillison ML (2010) Human papillomavirus and survival of patients with oropharyngeal cancer. N Engl J Med 363(1):24-35. https://doi.org/10.1056/NEJMo a0912217

2. Fakhry C, Zhang Q, Nguyen-Tan PF, Rosenthal D, El-Naggar A, Garden AS, Soulieres D, Trotti A, Avizonis V, Ridge JA, Harris J, Le QT, Gillison M (2014) Human papillomavirus and overall survival after progression of oropharyngeal squamous cell carcinoma. J Clin Oncol 32(30):3365-3373. https://doi.org/10.1200/ JCO.2014.55.1937

3. Guo T, Qualliotine JR, Ha PK, Califano JA, Kim Y, Saunders JR, Blanco RG, D’Souza G, Zhang Z, Chung CH, Kiess A, Gourin CG, Koch W, Richmon JD, Agrawal N, Eisele DW, Fakhry C (2015) Surgical salvage improves overall survival for patients with HPV-positive and HPV-negative recurrent locoregional and distant metastatic oropharyngeal cancer. Cancer 121(12):1977-1984. https://doi.org/10.1002/cncr.29323

4. El-Naggar AK, Chan JKC, Grandis JR, Takata T, Slootweg PJ (2017) WHO classification of head and neck tumours, vol 9, 4th edn. Lyon, pp 134-138

5. Amini A, Jasem J, Jones BL, Robin TP, McDermott JD, Bhatia S, Raben D, Jimeno A, Bowles DW, Karam SD (2016) Predictors of overall survival in human papillomavirus-associated oropharyngeal cancer using the national cancer data base. Oral oncol 56:1-7

6. Nasman A, Attner P, Hammarstedt L, Du J, Eriksson M, Giraud G, Ahrlund-Richter S, Marklund L, Romanitan M, Lindquist D, Ramqvist T, Lindholm J, Sparen P, Ye W, Dahlstrand H, MunckWikland E, Dalianis T (2009) Incidence of human papillomavirus (HPV) positive tonsillar carcinoma in Stockholm, Sweden: an epidemic of viral-induced carcinoma? Int J Cancer 125(2):362-366. https://doi.org/10.1002/ijc.24339

7. Laco J, Vosmikova H, Novakova V, Celakovsky P, Dolezalova H, Tucek L, Nekvindova J, Vosmik M, Cermakova E, Ryska A (2011) The role of high-risk human papillomavirus infection in oral and oropharyngeal squamous cell carcinoma in non-smoking and non-drinking patients: a clinicopathological and molecular study of 46 cases. Virchows Arch 458(2):179-187

8. Henderson BE, Feigelson HS (2000) Hormonal carcinogenesis. Carcinogenesis 21(3):427-433

9. Narod SA, Sopik V, Sun P (2017) Which women decide to take tamoxifen? Breast Cancer Res Treat. https://doi.org/10.1007/ s10549-017-4226-4

10. Blesa J, Candel VA, Marco VG, Giner-Bosch V, Pulla MP, Canales $\mathbf{J}$ (2010) Experience with fulvestrant acetate in castrationresistant prostate cancer patients. Ann Oncol 21(5):1131-1132

11. Ojanotko-Harri A, Forssell H, Laine M, Hurttia H, Bläuer M, Tuohimaa P (1992) Immunohistochemical detection of androgen receptors in human oral mucosa. Arch Oral Biol 37(6):511-514

12. Ruizeveld de Winter J, Trapman J, Vermey M, Mulder E, Zegers ND, van der Kwast TH (1991) Androgen receptor expression in human tissues: an immunohistochemical study. J Histochem Cytochem 39(7):927-936

13. Rades D, Seibold ND, Schild SE, Bruchhage KL, Gebhard MP, Noack F (2013) Androgen receptor expression: prognostic value in locally advanced squamous cell carcinoma of the head and neck. Strahlenther Onkol 189(10):849-855. https://doi.org/10.1007/ s00066-013-0389-z

14. Gonzalez LO, Corte MD, Vazquez J, Junquera S, Sanchez R, Alvarez AC, Rodriguez JC, Lamelas ML, Vizoso FJ (2008) Androgen receptor expresion in breast cancer: relationship with clinicopathological characteristics of the tumors, prognosis, and expression of metalloproteases and their inhibitors. BMC Cancer 8:149. https://doi.org/10.1186/1471-2407-8-149

15. Luk PP, Weston JD, Yu B, Selinger CI, Ekmejian R, Eviston TJ, Lum T, Gao K, Boyer M, O’Toole SA, Clark FR, Gupta R (2016) Salivary duct carcinoma: clinicopathologic features, morphologic spectrum, and somatic mutations. Head Neck 38(Suppl 1):E1838 E1847. https://doi.org/10.1002/hed.24332

16. Williams L, Thompson LD, Seethala RR, Weinreb I, Assaad AM, Tuluc M, Din NU, Purgina B, Lai C, Griffith CC (2015) Salivary duct carcinoma: the predominance of apocrine morphology, prevalence of histologic variants, and androgen receptor expression. Am J Surg Pathol 39(5):705-713

17. Wu TF, Luo FJ, Chang YL, Huang CM, Chiu WJ, Weng CF, Hsu YK, Yuan TC (2015) The oncogenic role of androgen receptors in promoting the growth of oral squamous cell carcinoma cells. Oral Dis 21(3):320-327

18. Valimaa H, Savolainen S, Soukka T, Silvoniemi P, Makela S, Kujari H, Gustafsson J-A, Laine M (2004) Estrogen receptorbeta is the predominant estrogen receptor subtype in human oral epithelium and salivary glands. J Endocrinol 180(1):55-62

19. Colella G, Izzo G, Carinci F, Campisi G, Lo Muzio L, D’Amato S, Mazzotta M, Cannavale R, Ferrara D, Minucci S (2011) Expression of sexual hormones receptors in oral squamous cell carcinoma. Int J Immunopathol Pharmacol 24(2_suppl):129-132

20. Nehse G, Tunn S (1994) Androgen and progesterone receptors in oral carcinoma. J Cranio-Maxillofac Surg 22(2):114-119

21. Bianchini C, Pastore A, Pelucchi S, Torreggiani E, Lambertini E, Marchesi E, Magri E, Frasson C, Querzoli P, Piva R (2008) Sex hormone receptor levels in laryngeal carcinoma: a comparison between protein and RNA evaluations. Eur Arch Otorhinolaryngol 265(9):1089-1094

22. Virolainen E, Tuohimaa P, Aitasalo K, Kyttä J, Vanharanta-Hiltunen R (1986) Steroid hormone receptors in laryngeal carcinoma. Otolaryngol Head Neck Surg 94(4):512-517

23. Berg NJ, Colvard DS, Neel HB III, Weiland LH, Spelsberg TC (1989) Progesterone receptors in carcinomas of the upper aerodigestive tract. Otolaryngol Head Neck Surg 101(5):527-536

24. James D. Brierley MKG, Christian W (2016) TNM classification of malignant tumours, 8th edn. John Wiley, New York

25. Jouhi L, Mohamed H, Makitie A, Remes SM, Haglund C, Atula T, Hagstrom J (2017) Toll-like receptor 5 and 7 expression may impact prognosis of HPV-positive oropharyngeal squamous cell carcinoma patients. Cancer Immunol Immunother. https://doi. org/10.1007/s00262-017-2054-3

26. Makinen LK, Hayry V, Atula T, Haglund C, Keski-Santti H, Leivo I, Makitie A, Passador-Santos F, Bockelman C, Salo T, Sorsa T, Hagstrom J (2012) Prognostic significance of matrix metalloproteinase- $2,-8,-9$, and -13 in oral tongue cancer. J Oral Pathol Med 41(5):394-399. https://doi.org/10.1111/j.1600-0714.2011.01110 .x

27. Bekkers R, van der Avoort I, Melchers W, Bulten J, de Wilde P, Massuger L (2004) Down regulation of estrogen receptor expression is an early event in human papillomavirus infected cervical dysplasia. Eur J Gynaecol Oncol 26(4):376-382

28. Haapaniemi A, Koivunen P, Saarilahti K, Kinnunen I, Laranne J, Aaltonen LM, Närkiö M, Lindholm P, Grénman R, Mäkitie A (2016) Laryngeal cancer in Finland: A 5-year follow-up study of 366 patients. Head Neck 38(1):36-43

29. Burke SC, Smith KV, Sharmin S, Winkelman C (2014) Prevalence of risk factors related to head and neck squamous cell carcinoma (HNSCC) among college students. Cancer Oncol Res 2(1):7-16

30. Marocchio LS, Giudice F, Corrêa L, Pinto DDS Jr, de Sousa SOM (2013) Oestrogens and androgen receptors in oral squamous cell carcinoma. Acta Odontol Scand 71(6):1513-1519

31. Goulioumis AK, Varakis J, Goumas P, Papadaki H (2011) Androgen receptor in laryngeal carcinoma: could there be an 
androgen-refractory tumor? ISRN Oncol 2011:180518. https:// doi.org/10.5402/2011/180518

32. Zhang Y, Pan T, Zhong X, Cheng C (2015) Androgen receptor promotes esophageal cancer cell migration and proliferation via matrix metalloproteinase 2. Tumour Biol 36(8):5859-5864. https ://doi.org/10.1007/s13277-015-3257-x

33. Jia M, Andreassen T, Jensen L, Bathen TF, Sinha I, Gao H, Zhao C, Haldosen L-A, Cao Y, Girnita L (2016) Estrogen receptor $\alpha$ promotes breast cancer by reprogramming choline metabolism. Cancer Res 76(19):5634-5646

34. López-Romero R, Garrido-Guerrero E, Rangel-López A, ManuelApolinar L, Piña-Sánchez P, Lazos-Ochoa M, Mantilla-Morales A, Bandala C, Salcedo M (2013) The cervical malignant cells display a down regulation of ER- $\alpha$ but retain the ER- $\beta$ expression. Int J Clin Exp Pathol 6(8):1594-1602

35. Ishida H, Wada K, Masuda T, Okura M, Kohama K, Sano Y, Nakajima A, Kogo M, Kamisaki Y (2007) Critical role of estrogen receptor on anoikis and invasion of squamous cell carcinoma. Cancer Sci 98(5):636-643. https://doi.org/10.111 1/j.1349-7006.2007.00437.x

36. Gingelmaier A, Gutsche S, Mylonas I, Shabani N, Kuhn C, Kunze S, Jeschke U, Friese K (2007) Expression of HPV, steroid receptors (ER $\alpha, E R \beta, P R-A$ and PR-B) and inhibin/activin subunits ( $\alpha$, $\beta A$ and $\beta B$ ) in adenosquamous endometrial carcinoma. Anticancer Res 27(4A):2011-2017

37. Grimm M, Biegner T, Teriete P, Hoefert S, Krimmel M, Munz A, Reinert S (2016) Estrogen and progesterone hormone receptor expression in oral cavity cancer. Med Oral Patol Oral y Cir Bucal 21(5):e554

38. Boukari R, Marcouiller F, Joseph V (2015) Relative contribution of nuclear and membrane progesterone receptors in respiratory control. In: Arterial chemoreceptors in physiology and pathophysiology. Springer, Cham, pp 261-267

39. Buttarelli M, Mascilini F, Zannoni GF, Ciucci A, Martinelli E, Filippetti F, Scambia G, Ferrandina G, Gallo D (2017) Hormone receptor expression profile of low-grade serous ovarian cancers. Gynecol Oncol 145(2):352-360

40. D'Amato NC, Gordon MA, Babbs B, Spoelstra NS, Butterfield KTC, Torkko KC, Phan VT, Barton VN, Rogers TJ, Sartorius
CA (2016) Cooperative dynamics of AR and ER activity in breast cancer. Mol Cancer Res 14(11):1054-1067

41. Li R, Wheeler T, Dai H, Frolov A, Thompson T, Ayala G (2004) High level of androgen receptor is associated with aggressive clinicopathologic features and decreased biochemical recurrence-free survival in prostate: cancer patients treated with radical prostatectomy. Am J Surg Pathol 28(7):928-934

42. Kauffman EC, Robinson BD, Downes MJ, Powell LG, Lee MM, Scherr DS, Gudas LJ, Mongan NP (2011) Role of androgen receptor and associated lysine-demethylase coregulators, LSD1 and JMJD2A, in localized and advanced human bladder cancer. Mol Carcinog 50(12):931-944

43. Wikström P, Marusic J, Stattin P, Bergh A (2009) Low stroma androgen receptor level in normal and tumor prostate tissue is related to poor outcome in prostate cancer patients. Prostate 69(8):799-809

44. Magri F, Capelli V, Rotondi M, Leporati P, La Manna L, Ruggiero R, Malovini A, Bellazzi R, Villani L, Chiovato L (2012) Expression of estrogen and androgen receptors in differentiated thyroid cancer: an additional criterion to assess the patient's risk. Endocr Relat Cancer 19(4):463-471

45. Lukits J, Remenar E, Rásó E, Ladányi A, Kásler M, Tímár J (2007) Molecular identification, expression and prognostic role of estrogen-and progesterone receptors in head and neck cancer. Int J Oncol 30(1):155-160

46. Chen R, Yu Y, Dong X (2017) Progesterone receptor in the prostate: A potential suppressor for benign prostatic hyperplasia and prostate cancer. J Steroid Biochem Mol Biol 166:91-96

47. Carey T, Grenman R, Virolainen E, Shapira A (1987) In vitro effects of tamoxifen on UM-SCC head and neck cancer cell lines: Correlation with the estrogen and progesterone receptor content. Int J Cancer 39(1):77-81

48. Hagedorn HG, Nerlich AG (2002) Analysis of sex-hormonereceptor expression in laryngeal carcinoma. Eur Arch Oto-RhinoLaryngol. 259 (4):205-210

49. Scambia G, Panici PB, Battaglia F, Ferrandina G, Almadori G, Paludetti G, Maurizi M, Mancuso S (1991) Receptors for epidermal growth factor and steroid hormones in primary laryngeal tumors. Cancer 67(5):1347-1351 